\title{
Workplace Violence and Harassment against Women in Transition Countries: The Case of Albania
}

\author{
Darina Çoni (Kacollja) \\ $\mathrm{PhD}$ in Sociology, \\ Department of Social Sciences, \\ University "Aleksandër Xhuvani", \\ Elbasan, Albania
}

\begin{abstract}
This study identified the extent of violence in the workplace against women in Albania. For this purpose, data were considered from the survey completed by 513 women in work relationship, between the ages of 24 and 60. About 92 percent of the respondents claimed to have been violated at least once in the workplace. Violence against women in the workplace involves, not only psychological, but also physical and sexual violence. This violence is largely exercised by persons within the environments where women work. The study also reveals why they do not seek help and why they do not publicly denounce these cases of violence. The main problem relates to state institutions that are supposed to bring relief to these cases. Some women declare that they do not trust these institutions in solving problems at the workplace.
\end{abstract}

Keywords: Violence at Work, Women, Albania, Transition

\section{Introduction}

This study examined the spread of violence in the workplace against women. The study sheds light on the actions or misconduct towards women in the workplace and who cause them. "This violence is affected by the culture, the climate in the workplace, the communication and personality of the individual" (Ferrari and Penati 2011, 20). In Albania, unlike domestic violence and violence in schools, where there are some national studies, more is talked about this in TV and in written media. Although regarding violence in the workplace there are virtually no studies, less is talked about this phenomenon in media. Generally, in transition countries, discussions are more about poverty and unemployment; and very little is done about those at work, the problems and difficulties they face. Work is closely associated with values, such as selfconfidence, human dignity, and the purpose of life. As Kabo points out, "When you are unemployed, you lack one of the elements of civic and personal security: 'feel that you are needed'; the unemployed is spiritually crumpled. Unemployment and seeking a job make the individual lose hope and confidence. They are depersonalized in front of family members, their touchiness is hurt and cannot maintain the legitimate authority of the 


\section{Journal of International Cooperation and Development \\ www.richtmann.org/journal \\ Vol 3, No 1, May 2020}

parent or responsible family" $(2006,269)$.

Women have also had difficulties finding jobs because of the large economic crisis that swept across Albania after the collapse of the communist system in 1991. Many factories, plants, and workshops were closed and hundreds of thousands of people were left out of work, both males and females. "The IMF Economic Report for Albania of year 1994, gives the level of decline, in production by 50 percent by the end of 1990 to mid1992... Moreover, the level of decline in output in Albania during this period was higher than the one that suffered the world during the great depression of 1929-33" (Hana and Telo 2005, 61).

This situation of the economy in the 1990s is well described by Pettifer and Vickers, as they argued "Albania's economic development between 1992 and 1996 was based on many illusory premises, but in reality it was hostage to the instant accumulation of multiple remittances by emigrants, which were strong and overvalued currencies in the domestic market. This coincided with the total bankruptcy of most state-owned enterprises and the many transition problems in the agricultural sector. Immigrants were accused of irresponsibility and naivety in funding pyramid schemes, but most people then had little chance of investing money into real businesses" $(2007,8)$.

"But during 1991, which represented the beginning of the transition, the assistance (paid to unemployed jobseekers) got bigger and by the protective instrument, it returned to the lifestyle. According to official data, during 1991, 114 thousand workers were paid by 80 percent, with over 10 million dollars" (Shahollari 2009, 213).

Due to high unemployment and poverty, many pyramid-leasing firms were scattered during 1991-1996, paying for deposits of citizens with super-high interests. "The company 'Xhaferri' received 100 dollars as loan and after three months the lender received 320 dollars from the firm. The average profit rate was $73.3 \%$ per month or $880 \%$ annual interest" (Dervishi, n.d. 359). Companies with pyramid schemes, such as Vefa and Xhaferi filled public television, advertising themselves as successful companies. This 'disease' spread like the speed of a cyclone; thousands of people invested their savings into these so-called successful firms. Vickers describes this phenomenon as follows: "The thousands of indifferent investors were standing in the queues in the early hours of the morning to introduce their laborious savings, most of which were provided by doing heavy arm jobs in Greece. A lot of people sold their houses to bring possibly in pyramids bigger amounts of money. The schemes were a powerful magnet, which released a ray of hope in a place where the average monthly salary was not more than $\$$ 100 and with a high level of unemployment rate" (2008: 380).

In this case, not only various individuals, but also seemingly more prudent and responsible persons in state institutions failed to realize and rationalize how these administrators of these so-called successful firms, without high professional training in economy, without any foreign language for international trade, could get money at an interest of up to $880 \%$ per year, out of any economic law. The mobs have never known 


\section{Journal of International Cooperation and Development \\ www.richtmann.org/journal \\ Vol 3, No 1, May 2020}

the thirst for the truth. They require illusions which they cannot live without. To them, unreal has always priority over reality, the unreal acts on them almost the same as reality (Freud 2004). When pyramiding companies were unable to return their savings to the people, demonstrations of the disillusioned escalated, seeking their own money. "We want our money!" was the battle cry heard during these protests. These demonstrations turned into rebellion, which was accompanied by the opening of weapons depots, by arming the population. In 1997, almost all of Albania was involved in anarchy.

Under those circumstances, those who had a job were privileged. There was no question about the environment and the communication climate in the workplace. The employer could threaten employees at any moment with the phrase, "If you want, stay, if not, go away, many others seek for a job." The State during this period was not strong, had serious problems with securing public peace, and could not deal with providing the best conditions in the workplace. This created, in the society, the opinion that it is a disaster to work for the private sector, that it exploits you maximally and does not appreciate at all. In some respects, this opinion was grounded. Thus, a new phenomenon emerged and developed in the private sector, which did not exist before the 1990s, informal employment. There were employees forced to work without social and health insurance. This phenomenon, not only in this region, but throughout Albania, spread widely. As Hana and Telo point out, "informal employees in Albania account for about 43.4 percent in year 2000 " $(2005,322)$. This phenomenon, continues to be worrying, as is the case with this study. For these reasons, women prefer to work in public institutions, because they have insurance benefits; their birth leave and annual leave are paid, despite low wages and problems, when there is political rotation. "The education sector is the most preferred employment sector of women in the city of Elbasan. About $86.4 \%$ of 9-year school teachers and $67.7 \%$ of high school teachers are women" (Municipality of Elbasan, n.d. 29). In country scale, in 2014-2015, teachers' staffs in the 9 -year schools consist of $73 \%$ women, and in secondary schools, $65 \%$ consist of women (INSTAT, 2017).

From the data on participation in the labour market, $60.8 \%$ are women and $76.8 \%$ are men. In year 2014, 51.3\% are women and $72.2 \%$ are men. Because of the distressing levels of unemployment, women are, in many cases, accept the first job offer, and they cannot seek a job in their own profession, or a job where they think they are professionally capable.

State institutions during this time not only failed to intervene to regulate working conditions in the private sector, but, their actions, in some cases, increased the violence exercised to employees working in the administration.

During these 23 years, any political force that came to power began to dismiss some of the administration employees from work, replacing them with militants. So only for the years 2005-2006, 395 people have been dismissed from the public 


\section{Journal of International Cooperation and Development \\ www.richtmann.org/journal \\ Vol 3, No 1, May 2020}

administration in the district of Elbasan (Mesi 2013). Also, after the 2013 elections, a number of people have been dismissed from the public sector. This sector should have been the first to guarantee employee safety and not exploit them for political interests. Thus, during the 2013 elections, both political forces exerted pressure on the administration to participate in the rallies. The first report by OSCE/ODIHR observers confirms that the state administration was used for election campaign and that employees were dismissed because of disobedience to become part of the ruling party campaign (2013). There was pressure on the administration employees that in every political rotation they could be dismissed from work, even though they worked devoutly.

There are many times in the print media, where job vacancys competitions in state institutions are fictitious, because the workplace has long been occupied. Also, before the elections, many people have been employed only on provisional contracts for short periods of time, up to 3 months (Hoxhaj 2013). All this influence of politics on the employees makes them insecure. Though they have a regular contract, they can be dismissed at any time. This study has also highlighted the factors that hinder the career growth of women in the workplace. Patriarchal mentality is one of the dominant factors that hinders women's career. This mentality continues to be reflected today in the patriarchal minds of a sector of society. As noted by Mark et al. "Our socio-cultural environment carries inherent patriarchal values and outlook, as such, it heavily affects the position of women, historically grown under a discriminatory gender tradition" (2008: 16).

Hooks inter alia writes: "Men as a group have and continue to benefit more from patriarchs, assuming they are superior to females and need to rule. But all these benefits are coupled with a price. In exchange for the benefits that men have benefited from patriarchs, they are required to own women, to use and to press them, using violence so that patriarchs is not threatened. Most men find it difficult to be patriarchs. But they are afraid to throw away these benefits. They are not sure what will happen to the world they know closely if the patriarch is rolling. So, they find it easier to support male domination, even though in their minds and hearts they know very well that such a thing is wrong" (2007: 13). Historically, in the patriarchal society the man has been dominant; he made the law in the family and social life in general. The young boys in patriarchal societies are educated on how to deal with women. They should always command, otherwise society begins and goes into play, as French also points out: "Since young boys, they hear repeatedly that the real men control women, that is, they control their behaviour and have the right to insult and to physically abduct them. This is so important for the demonstration of manhood, that the man who treats the woman in a relationship of equality and mutual respect sometimes behaves in the presence of other men with a dominant attitude towards her. This behaviour suggests that they believe that 'manhood' is not something internal to men, but that it depends very much on the 


\section{Journal of International Cooperation and Development \\ www.richtmann.org/journal \\ Vol 3, No 1, May 2020}

opinion of other men and the presence of a person or group that has to vanquish" $(2007,213)$. While young girls are bred to not react and obey male domination because poor people must have someone strong enough to protect them, but also support them economically. A relationship of this kind puts the woman in a difficult position, which is also based on the conditions of a country like Albania, and is often associated with full economic dependency, with no choice for a part of women.

The individual, right at birth, with the beginning of his identity and later his personality, starts with the family, in a close relationship with the mother and then with the father and the relationships between them form part of the individual's personality. Relationships in society, communication with it, giving and receiving from society begin to structure the personality of the individual. As Vassaf points out, "The process of socialization through which we move to maturity is a process in which we learn to agree. We are taught to agree with all the rules, from the rules of simple children's play to the laws of the institutions. In the process of socialization there is no room, no single moment for disagreement. It is thought that it is good to agree. In a family, school, religion or government, disagreeing is not good, it is rude, dangerous" $(2010,160)$.

To highlight the proliferation of violence against women in the workplace, this research raised the following questions:

Question 1: How widespread is violence in the workplace against women and who causes it?

Question 2: How difficult is it for women to become a career professional and what is the cause of this difficulty?

Question 3: What are the reasons women do not protest about workplace violence?

\section{Methodology}

This study was carried out during 2013-2014 following the quantitative research method. A structured and semi-structured questionnaire was formulated. After the final consultation with the Department of Sociology at the University of Tirana, the process of filling in the questionnaires started. To fill in the questionnaires, the Elbasan Region was chosen because it lies both in the southern and northern Albanian areas. The sample was calculated, keeping the ratio for each municipality depending on the number of residents. The age of those interviewed ranged from 24 to 60 years. Of which, according to the census of 2011, were interviewed by age group, 24 to 29 years old were completed by $17.2 \%$ (88) of participants, $30-34$ years old were completed by $12.5 \%$ (64), $35-39$ years old were completed by $13.8 \%(71), 40-49$ years old by $28.8 \%(148)$, and 50 60 years old by $27.7 \%$ (142).

To conduct interviews were used a group of goodwill and well trained women with high education in the social field. Each group that completed the survey on the field was 


\section{Journal of International Cooperation and Development \\ www.richtmann.org/journal \\ Vol 3, No 1, May 2020}

supervised by the area's responsible person, enabling a more correct functioning of the working groups during the filling in of the questionnaire. A total of 513 questionnaires were completed.

\section{Data analysis}

This study used quantitative data to examine the frequency and cause of violence in the workplace against women. The data from the questionnaire supplementation were analyzed using the statistical package JASP, version 08.4

\section{Results}

Women in the workplace were violated not only psychologically, but physically and sexually as well. From the questionnaire data, 92\% noted they were violated (Table 2). Of these, $88.9 \%$ were psychologically violated, $1.9 \%$ sexually violated, and $1.4 \%$ physically violated (Table 1). Further, informal employment was found to be a phenomenon, where about $9.2 \%$ work without health and social security payments (Table 1).

Table 1. Acts of misconduct and violence that have occurred in the workplace

\begin{tabular}{|lcc|}
\hline \multicolumn{2}{|c|}{$\begin{array}{l}\text { Which of the following actions happened to you in the workplace and } \\
\text { which did you find more troubling? }\end{array}$} \\
\hline & Frequency & Percentage \\
\hline Cry you out & 84 & 16.4 \\
\hline Insulted you & 83 & 16.2 \\
\hline Physically threatened you & 7 & 1.4 \\
\hline Hit you & 7 & 1.4 \\
\hline Threatened that you will be fired & 51 & 9.9 \\
\hline Did not appreciate your work & 109 & 21.2 \\
\hline Despised you & 14 & 2.7 \\
\hline Sexually harassed you & 10 & 1.9 \\
\hline Put pressure on you to do a job out of his/her wish & 6 & 1.2 \\
\hline Worked in a place without the technical security necessary for life & 14 & 2.7 \\
\hline Worked on a lower salary than the legal one & 41 & 8.0 \\
\hline Worked without social and health insurance & 47 & 9.2 \\
\hline I do not know/no answer & 40 & 7.8 \\
\hline Total & 513 & 100 \\
\hline
\end{tabular}




\section{Journal of International Cooperation and Development}

www.richtmann.org/journal

Vol 3, No 1, May 2020

Table 2. The frequency of violence in the workplace

\begin{tabular}{|lcc|}
\hline & Frequency & Percentage \\
\hline Several times a week & 14 & 2.7 \\
\hline Several times a month & 33 & 6.5 \\
\hline Several times a year & 173 & 33.7 \\
\hline Rarely than once a year & 252 & 49.1 \\
\hline Never & 41 & 8.0 \\
\hline Total & $\mathbf{5 1 3}$ & $\mathbf{1 0 0}$ \\
\hline
\end{tabular}

Not only is the high percentage of women who have experienced violence at work alarming, but so is the frequency. From the questionnaire data, it turned out that about $42.9 \%$ stated that these violent actions have occurred several times a year, up to several times a week (Table 2).

From the data, domestic violence is dominant by $72.5 \%$, of which $44.1 \%$ is violence exercised by the employer. External violence exercised by non-employed persons is $25.1 \%$ (Table 3).

Although the percentage of women who have been victims of workplace violence is problematic, very few are able to seek help. About $89.5 \%$ of women have not asked for help about workplace violence. About $56.2 \%$ of the respondents who have reported problems with institutions do not know or do not trust these institutions that specialize in violence at work (Table 4).

Table 3. The perpetrators of these actions

\begin{tabular}{|lcc|}
\hline & Frequency & Percentage \\
\hline From your colleagues & 46 & 9.9 \\
\hline From your colleagues & 35 & 7.5 \\
\hline From outsiders but related to your job (client) & 34 & 7.3 \\
\hline By managers & 28 & 6.0 \\
\hline By managers & 23 & 5.0 \\
\hline From your employer & 158 & 34.0 \\
\hline From your employer & 47 & 10.1 \\
\hline From outsiders who are not related to your work & 83 & 17.8 \\
\hline Other & 11 & 2.4 \\
\hline Total & $\mathbf{4 6 5}$ & $\mathbf{1 0 0}$ \\
\hline
\end{tabular}




\section{Journal of International Cooperation and Development \\ www.richtmann.org/journal \\ Vol 3, No 1, May 2020}

Table 4. Reasons not to ask for help

\begin{tabular}{|lcc|}
\hline \multicolumn{3}{|c|}{ If you have not asked for help, why? } \\
\hline & Frequency & Percentage \\
\hline You do not know any institution that provides help. & 142 & 30.9 \\
\hline Distrust of institutions & 116 & 25.3 \\
\hline Fear of losing your job & 82 & 17.9 \\
\hline Fear that they would not believe you & 81 & 17.7 \\
\hline Fear of society & 13 & 2.8 \\
\hline Fear of family & 11 & 2.4 \\
\hline Others & 7 & 1.5 \\
\hline I do not know/No answer & 7 & 1.5 \\
\hline Total & $\mathbf{4 5 9}$ & $\mathbf{1 0 0}$ \\
\hline
\end{tabular}

Table 5. Fear of losing the job

\begin{tabular}{|lcc|}
\hline \multicolumn{2}{|c|}{$\begin{array}{c}\text { How fearful are you that they can get rid of you without taking into } \\
\text { consideration the employment contract? }\end{array}$} \\
\hline & Frequency & Percentage \\
\hline Very much & 100 & 19,5 \\
\hline Somewhat & 111 & 21,6 \\
\hline Little & 110 & 21,4 \\
\hline Not at all & 108 & 21,1 \\
\hline I do not know/No answer & 84 & 16,4 \\
\hline Total & $\mathbf{5 1 3}$ & $\mathbf{1 0 0}$ \\
\hline
\end{tabular}

Table 6. Factors that hinder the advancement of women in professional career

\begin{tabular}{|lcc|}
\hline & Frequency & Percentage \\
\hline Patriarchal mentalities & 231 & 45,0 \\
\hline Lack of support from family & 70 & 13,7 \\
\hline Commitment to housework & 64 & 12,5 \\
\hline Masking in the direction & 57 & 11,1 \\
\hline Lack of confidence & 20 & 3,9 \\
\hline Husband's jealousy & 53 & 10,3 \\
\hline Others & $\mathbf{7}$ & 1,4 \\
\hline I do not know/No answer & 11 & 2,1 \\
\hline Total & $\mathbf{5 1 3}$ & $\mathbf{1 0 0}$ \\
\hline
\end{tabular}

\section{Discussion}

The data from this study showed some of the worst actions or misconduct that have 


\section{Journal of International Cooperation and Development \\ www.richtmann.org/journal \\ Vol 3, No 1, May 2020}

been done to women in the workplace and how often they are faced with these actions. Despite the prolonged transition in Albania where finding a job is very difficult, workplace violence should be taken seriously. Not only should the number of relevant studies be increased, but concrete legal measures should be taken to minimize this violence. A national strategy should be developed against this violence. From the study's data, the domestic violence that prevails is mostly carried out by management leaders and employers.

Lack of strategy and inaction by state institutions are highlighted in the survey's response, where employees do not know the institutions that bring relief to these cases. Some do not ask for help or some believe that by complaining, there will be no actions against perpetrators and to have them dismissed from their positions is unlikely. "The female, the woman is also distinguished for her patience. Patience for hard work and patience for delicate work. Endurance to end a job. Endurance to sit all night close to her seriously ill child. Patience with such a resilient spirit as the people say, 'The woman is like a cat, she has seven souls'" (French 2007, 22).

The study shows that majority of the women are afraid of being dismissed from their positions regardless of having a work contract. Sandberg inter alia wrote: "There is a great fear that, by raising their voices, they will aggravate the situation, be punished or be fired. Clearly, the endurance of injustice seems the safest way to survive in that environment" $(2013,174)$. The fear of being fired, among women in Albania is very current. In 2015 alone, the State has paid about \$30 million for unjust discharges (Manjani 2016).

The data extracted from the study on sexual harassment in the workplace need to be looked at in more detail because these phenomena are hardly accepted by women in post-communist countries because of the social opinion that can prejudge them.

"Women in post-communist countries often admit brutal behaviour, including sexual harassment, as a show of 'manhood' and to date, there has been no protest against these phenomena. Stereotypes in the behaviour of men and women have almost not changed at all. Under the totalitarian regime, issues of attitudes and manners of men and women were not dealt with in sociological studies or in the popular press. Recently, the sociology was simply transformed into a state ideology that is the reason why it did not address this issue. Therefore, today, men and women find it difficult to understand the causes of some of their reactions and attitudes. It was difficult for the citizens of post-communist countries to reflect on their behaviour.

At present, much attention is being paid to economic issues, consumer issues, free market and political transformations, and again, gender issues are not being given due care (Davies 2001, 123).

These stereotypes are still going on. Women are afraid and express reservations about sexual violence in the workplace. They know they may end up being blamed: that they wanted it themselves; women flirt with the bosses; they dress up sexy when they 


\section{Journal of International Cooperation and Development \\ www.richtmann.org/journal \\ Vol 3, No 1, May 2020}

go to work; they themselves went to that job, among others. All of this is done just to make women feel guilty of being the cause of such behaviours. The conservative opinion, which is in a part of society, comes to the point of prejudging these women as if their career at work has been achieved because of sexual flirtation with their bosses. These are ways to denigrate women who work and become economically independent of men. Davies emphasizes: "In other words, how many women are unjustly accused of having moved forward by the force of their 'seduction', with the intention of invalidating them professionally" (2001: 105).

Certainly, there may be special cases that women may use sexual attraction to advance their careers, but these are sporadic cases, which should not prejudice all women for their careers. "Even to go out with the boss to 'raise up' and sexual harassment stems from the same system of male hierarchical power and needs to be analyzed together, but they are not at the same level. Therefore, sexual harassment cannot be justified or ignored, based on the 'argument' those women sometimes want to have sex with their superiors in order to benefit their careers" (ibid. 105).

Although the percentage of women who have been victims in the workplace violence is problematic, very few are able to seek help and almost no cases have been made public or have ended up in court for this reason.

State institutions should be serious about dealing with violence in the workplace. It is necessary to set up structures to protect employees from abuses. Violence at work, like any other manifestation of violence, is difficult to prove, so it is very difficult to appeal to the court.

A national strategy to avoid "work in black", such as work without social and health insurance, should be drafted and implemented as soon as possible. This study shows that it is tormenting for some of the employees. However, in a UNDP study conducted in 2012 in vulnerable strata, $93 \%$ and $88 \%$ of those from Rome and Egypt, respectively, work without social security (UNDP, 2012). This has been a continuing phenomenon in Albania during the transition years, because the number of families in these communities who benefit from pension is $12.5 \%$ (Rome) and $16.7 \%$ (Egypt) of the population. Note that the pension benefit in Albania starts after you have worked 35 years of insurance work and have reached the age of 65 for men and 60 for women (UNDP 2012).

In Europe, a wide-ranging study on workplace violence has been undertaken by the European Agency for Safety and Health at Work in 31 European countries. It turned out that in Turkey, violence or threat of violence in the workplace is very disturbing for $65 \%$ of workers; in Portugal, it is very worrying for $53 \%$ of employees; and in Romania, about $44 \%$. While in Estonia, violence or threat of violence at work is very worrying for about $1.7 \%$ of employees. In the European Union, the violence or threat of violence at work is $18.5 \%$ (osha.europa.eu/en/surveys-and-statistics-osh/esener/2009). This study also confirms that the countries that experienced the most economic crisis are those where 


\section{Journal of International Cooperation and Development \\ www.richtmann.org/journal \\ Vol 3, No 1, May 2020}

violence in the workplace is most troubling.

From the data of this study, for bullying or harassment, (i.e., abuse, humiliation or assault by colleagues or superiors), Turkey is in the first place with $75 \%$ of respondents saying it is very disturbing; in Portugal 44\%; and in Romania and Norway, $44 \%$. In Slovakia, this is $0.4 \%$ and in the European Union, it is $17.9 \%$ (osha.europa.eu/en/surveys-and-statistics-osh/esener/2009).

From the study conducted by the European Agency for Safety and Health at Work, respondents were asked about each event that happened to them in their workplace, how disturbing it was: very disturbing, somewhat disturbing, not worrying, unanswered. In this interview, respondents should only respond to the action that had happened to them in the workplace and that they considered most disturbing.

This study has some limitations. The study of workplace violence against women, not including males in this study, should also have been done nationally, due to the lack of such studies. Further, the impact of this violence on labour productivity was not studied.

\section{References}

Davies, M. (2001). Dhuna dhe gratë [Violence \& Women]. Tiranë: Dituria.

Dervishi, Z. (n.d.). Nëpër degzime të kultuës shqiptare [Through the ramifications of Albanian culture]. Tirana: Emal.

European Agency for Safety and Health at Work.Retrieved from. www.osha.europa.eu (accessed May 06, 2015).

Ferrari, G and Penati, V. (2011). II Mobbing e le violenze psicologiche [Mobbing and psychological violence]. Milano: Ferrari Sinibaldi.

French, M. (2007). Fight against women. Tiranë: Dora d'Istria.

Freud, Z. (2004). Psikologjia e turmave [Crowd Psychology]. Tirana: Fan Noli.

Hana, L., and Telo, I. (2005). Transition in Albania: Achievements \& Challenges. Tirana: Mësonjëtorja.

Hooks, B. (2007). Feminizmi është për të gjithë [Feminism is for everyone]. Tiranë: Dudaj.

Hoxhaj, Ermelina. (2013, May 12). 1 mijë infermierë kontrata -3 mujore [1 thousand nurses, working contracts of 3 months]. Gazeta shqiptare, p. 3.

Institute of Statistics of Republic of Albania. (2012). Census- Elbasan 2011. Tirana: Adel print Institute of Statistics of Republic of Albania. (2015). Labour Market 2014. Tirana: Adel print. Kabo, P. (2006). Autoritarizëm në tranzicion [Authoritarianism in transition]. Tirana: Plejad.

Manjani, O. (2016, January 19). Largimet nga puna, kostoja në buxhet 30 milion dollar [dismissal from work,cost in the budget, 30 million dollars]. Gazeta shqiptare, p. 5.

Marku, M., Berisha, E., Gjermeni, E., and Shtraza, I. (2008). Domestic violence in the media focus. Tiranë: Mediaprint.

Mesi, H. (2013, October 6). Shkarkimet politike në administrate [Dismissals from work, political, in administration]. Gazeta shqip, p. 5. 


\section{Journal of International Cooperation and Development}

www.richtmann.org/journal

Vol 3, No 1, May 2020

Municipality of Elbasan. (n.d.). Report on the Position of Women and Girls in the Municipality of Elbasan. Tirana: Pegi.

Pettifer, James., and Vickers, Miranda. (2007). Albanian Issue: Reformation of Balkan. Tirana: Bota shqiptare.

Shahollari, L. (2009). Në tunelin e tranzicionit [In the transition Tunnel]. Tiranë: Emal.

Sheryl, Sandberg. (2013). Të bëjmë përpara [Let's move]. Tiranë: Pegi.

The first report by OSCE/ODIHR. (2013, June 8). Gazeta Shqip, p. 3.

United Nations (UNDP),(29.02.2012) A Needs Assessment Study on Roma and Egyptian Communities in Albania.(pdf) Retrieved from http://www.undp.org (accessed May 6, 2015). Vassaf, H.Y. Gunduz. (2010). Self-contained prisoners. Tiranë: Fan Noli.

Vickers, M. (2008). Albanians, A Modern History. Tirana: Bota Shqiptare 